\title{
Measuring Employability for Disadvantaged Unemployed People? Evidence from Survey and Register Data'
}

I Sofie Dencker-Larsen ${ }^{2}$

Postdoctoral Researcher, National Research Centre for the Working Environment (NRCWE), Denmark

\begin{abstract}
Disadvantaged unemployed Danes do not easily become re-employed. Previous literature has focused on unemployment versus employment. Expanding on this, the present article is a proposal to assess disadvantaged unemployed people's employability. On the basis of the literature, I investigate whether variables measuring health, well-being, self-efficacy, alcohol use, and drug use can be included into this measure of employability measured as subsequent re-employment. Data are on disadvantaged unemployment cash benefit recipients from the Copenhagen Unemployment and Well-Being Panel Survey (2013, 2014, N = 2400, analytical sample $N=956)$ and detailed register data on employment status measured weekly. The results from the analysis reveal that only parts of the proposed indicator are linked with subsequent re-employment, and comprehensive robustness checks reveal that the indicator lacks stability. However, the findings from the study can inform future studies aiming at developing an indicator of employability for disadvantaged unemployed people in Denmark and the other Nordic countries.
\end{abstract}

\section{KEYWORDS}

Factor structure / indicator / re-employment / stability / unemployment / validity

\section{Introduction}

nemployed people with social or health problems (disadvantaged unemployed people) do not easily become re-employed ${ }^{1}$. After three years, less than $20 \%$ of disadvantaged Danish unemployment cash benefit recipients (cash benefit recipients) assessed by caseworkers as experiencing barriers hindering them from re-employment ${ }^{2}$ are self-supported (The Danish National Audit, 2010), thus indicating re-employment. Furthermore, activation policies, widely used in the Nordic countries (Johansson, 2001) that are intended to increase re-employment chances, have motivation effects for unemployed people in general (e.g., Geerdsen, 2006) but do not appear to have positive effects for this group of disadvantaged unemployed people in particular (Pedersen, 2007; Skipper, 2010; The Danish National Audit, 2010). In fact, in 2010, The Danish National Audit Office issued a report that concluded that the activation of disadvantaged unemployed cash benefit recipients exerted no positive effect on subsequent re-employment (2010).

\footnotetext{
${ }^{1}$ You can find this text and its DOI at https://tidsskrift.dk/njwls/index.

${ }^{2}$ E-mail: sdl@nrcwe.dk. The majority of the work on this manuscript was carried out while affiliated with University of Copenhagen and SFI - The Danish National Centre for Social Research (now: VIVE the Danish Centre of Applied Social Science), Denmark.
} 
Rather than focusing exclusively on the end-outcome, re-employment, further steps on the way toward re-employment are likely key to understand and measure re-employment. To assess whether social policies, such as activation programmes, improve the re-employment chances of disadvantaged unemployed people in a figuratively stepwise manner, developing an indicator of the figurative distance, or employability, from re-employment of disadvantaged cash benefit recipients is crucial (based on, e.g., Bach, 2012; Graversen, 2011; Pedersen, 2007)3. From 2011 to 2015, I conducted a literature review $^{4}$, which revealed that physical or overall health (e.g., Carlier et al., 2014; Schuring et al., 2013), mental health (e.g., Bach, 2012; Lindegaard \& Rosholm, 2016), alcohol use (e.g., Bach, 2012; Claussen, 1999a), drug use and alcohol use (Sutton et al., 2004), and self-efficacy ${ }^{5}$ (e.g. Claussen, 1993; Lynd-Stevenson, 1999) are factors that are likely to affect re-employment chances.

There is an absence of indicators of subsequent re-employment to enable measuring the potential stepwise progression of unemployed people, their employability (Bach, 2012; Dencker-Larsen, 2013; Graversen, 2011; Larsen, 2012; Pedersen, 2007) ${ }^{6,7}$. Previous measures resembling indicators of employability have been designed primarily to function as screening tools. One such tool is the Australian Job Seeker Classification Instrument, which screens newly unemployed people for the risk of long-term unemployment (Graversen, 2011; Marston \& McDonald, 2008). This measure includes exogenous variables that are unlikely to change over time and therefore cannot be used to measure progression toward re-employment (Graversen, 2011) (similarly, and equally important, nor can they be used to measure regression from re-employment). Therefore, in this article, I develop and test an indicator of employability for disadvantaged cash benefit recipients.

By exploring the following three research questions, I develop and test an indicator of employability for disadvantaged cash benefit recipients: 1) What is the factor structure of variables that are likely to indicate employability for disadvantaged cash benefit recipients?; 2) Does each factor have predictive validity for subsequent re-employment?; and 3) Is the factor structure and predictive validity stable over time? The ambition of this study is to develop an indicator that can be used in Danish and Nordic evaluations of activation program participation. The analyses show three factors: health/well-being, health/self-efficacy, and alcohol use. The second factor, health/self-efficacy, has predictive validity for subsequent re-employment, and from the exploratory factor analysis repeated on the 2014 wave; the factor structure of the three factors shows a relative high degree of stability from 2013 to 2014, but the predictive validity appears to not be stable. From the confirmatory factor analysis, there appears to be instability between the 2013 and the 2014 factors. In conclusion, the indicator - as is - is not stable enough to be used in studies evaluating activation program participation. What the findings do, however, is take an important step by showing what works and what does not work when aiming at developing an indicator of employability for disadvantaged unemployed people.

Data for this study comprise data on disadvantaged unemployment cash benefit recipients provided by the Copenhagen Unemployment and Well-Being Panel Survey (2013, 2014; $\mathrm{N}=2400)$ and extensive register data for each respondent on employment status measured weekly. I conduct an analysis of these data in three parts. First, using exploratory factor analysis, I explore the factor structure of variables from the relevant themes that emerged from the literature review. This method reveals the factor structure

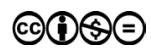


of constructs in the data from the first wave of the survey (i.e., 2013). Second, using prospective regression analysis, I investigate the predictive validity of the employability indicator by testing whether each factor of the indicator is linked with subsequent re-employment. Third, repeating the exploratory factor analysis and the regression analysis on the second wave of the survey (i.e., 2014) and using confirmatory factor analysis in the form of structural equation modelling, I investigate the stability of the indicator in relation to the data from the second wave of the survey (i.e., 2014).

\section{Institutional setting}

As one of the aims of developing an indicator measuring employability is to enable more nuanced analyses of social and labor market policies such as activation programs, I briefly describe the Danish activation landscape. Unemployed workers receive either unemployment insurance (UI) or universal cash benefits (for further information on the Danish unemployment benefits system, please see Svane-Petersen \& Dencker-Larsen, 2016). Cash benefits are typically lower than UI (OECD, 2009). The present study focuses on cash benefit recipients. They are required to participate in activation programs (The Danish Agency for Labour \& Recruitment, 2016). Activation programs may refer to courses, guidance, or on-the-job training at private or public companies. These programs are designed to improve the chances of (re-) employment (Jobnet, 2016), legitimize welfare benefit expenditure, and ensure that unemployed workers remain available for employment (Pedersen, 2007). It is not within the scope of the present article to discuss the pros and cons of activation programs, however, for an interesting discussion on broader labor market policy trends toward individualization, including activation policies, please see, for example, Hobbins (2016).

\section{Theoretical and empirical background}

Unemployment is considered to be a core cause of social marginalization and exclusion (Halvorsen, 2000). In a binary format, unemployment can be viewed as exclusion from the labor market, while employment can be seen as inclusion into the labor market. Unemployment, however, can also be viewed as degrees of marginalization from the labor market on a continuum ranging from social inclusion to social exclusion (Kristensen, $1999)^{8}$. Using this imagery, an unemployed person can be various degrees of proximity from re-employment. This is depicted in Fig. 1.

In parts of the literature, this distance to employment is labeled 'employability'. This term is often used about employers' interests in skills and personality traits of graduates

Figure I: Social marginalization.

Inclusion:
Employed

I use a similar figure in Larsen (2012). The figure is based on Svedberg's spectrum (as presented in Kristensen, 1999, p. 16). 
(Hillage \& Pollard, 1998). In the present study, however, I focus on the corner of the employability literature which addresses 'contextual factors', barriers which potentially hinder employment (Hillage \& Pollard, 1998); this could, for example, be poor health or poor mental well-being providing barriers for the unemployed person's job search or maintaining work tasks. On this basis, I hypothesize that if an unemployed person has a decrease in barriers hindering his or her re-employment (e.g., improved health status), his or her re-employment chances will also increase.

An important caveat is that the present study has a supply-side focus only (McQuaid \& Lindsay, 2005). It is likely that also the demand side, for example, attitudes of employers, can affect re-employment chances of disadvantaged cash benefit recipients (for this argument concerning older workers, please see Kadefors \& Hanse, 2012). For empirical reasons, the present study solely provides knowledge on barriers for individuals in investigating how these barriers are linked with subsequent re-employment. Future studies could benefit from building on this knowledge by adding observation or interview studies seeking to investigate the importance of employer bias and other demand-side aspects of re-employment chances.

When setting out to measure employability, several individual barriers are likely to be relevant, perhaps even simultaneously. One unemployed person may experience no personal issues hindering employment. Another may have issues stemming from drug use and illness. Participating in active labor market programs may affect these barriers (either increase or decrease the barriers). As a proxy of employability, I therefore focus on barriers that may hinder re-employment, while also being amenable to change over the course of participating in an activation program.

These barriers were located in a literature review on obstacles that may affect reemployment chances. The literature search was conducted primarily between 2011 and 2015. The review showed that physical or overall health, mental health, alcohol use, drug use, and job self-efficacy are potential barriers affecting re-employment. Studies have shown the importance of physical or overall health (e.g., Carlier et al., 2014; Schuring et al., 2013) and mental health on re-employment chances (e.g., Bach, 2012; Lindegaard \& Rosholm, 2016); additionally, studies have suggested the importance of alcohol use (e.g., Bach, 2012; Claussen, 1999a) and of both alcohol and drug use (Sutton et al., 2004) on re-employment chances. They have also highlighted the potential influence of self-efficacy (or indicators similar to self-efficacy such as job expectancy and being discouraged) on re-employment chances (Claussen, 1993; Lynd-Stevenson, 1999).

A literature review study from KORA et al. on re-employment chances reveals themes similar to those above (i.e., physical health and mental health, including substance abuse), along with barriers such as personal competences, social competences, and vocational skills (Kora et al., 2012). Accordingly, I include variables measuring health and substance use. I do not, however, include variables measuring other skills and competences. This is due to the intended use of the present indicator. The indicator is to be used in evaluations of shorter-term or longer-term activation programs. Such programs may either increase or decrease an unemployed person's employability and reemployment chances. Therefore, the included variables must enable fluctuations (both up and down) over time. During working age, skills and other competences are likely to either stagnate or increase over time, but are unlikely to decrease over time (at least during the relatively brief period during which a person participates in an activation program). Variables measuring, for example, skills, training, and education are therefore 
assessed to be irrelevant to include in the indicator of re-employment because they are unlikely to change or unlikely to decrease (this is also the case with variables such as age and country of origin that have been used in certain previously proposed indicators (Graversen, 2011)). Such factors, however, are likely useful for screening tools aimed at isolating subgroups of disadvantaged unemployed people.

\section{Methods and data}

\section{Methods}

Developing and testing a new indicator is arduous (Streiner et al., 2014) and can be approached from different angles (see, e.g., Daniel et al., 2009; Elo et al., 2003; Fugate \& Kinicki, 2008; Morisky et al., 1986). To develop an indicator of employability and test its predictive validity and the stability of the indicator over time, this study's analysis comprises three parts.

In the first part of the analysis, I use exploratory factor analysis to examine the factor structure of the indicator. Factor analysis reveals latent factors, which underlie manifest items, or variables. It enables combining several variables into one underlying factor, which indicates an overall theme shared by the included variables. Exploratory factor analysis can be used to test which variables may be combined into common latent factors. It can also be used to test the factor structure of indicators (see, e.g., Briggs \& Cheek, 1986; Fugate \& Kinicki, 2008). Exploratory factor analysis reduces redundancy and portrays latent structures shared by relevant variables (Briggs \& Cheek, 1986). Allowing the factors to be correlated rather than orthogonal, I chose to rotate them using oblique 'oblimin' rotation.

Factor analysis offers the advantage of revealing the latent structures of a chosen set of variables, yet it does not inherently have predictive value (Lanyon \& Goodstein 1982 in Briggs \& Cheek, 1986). To assess the predictive value of the derived factors on subsequent re-employment, I use a multivariate linear regression model (Agresti \& Finlay, 1997) to test the 2013 factors (including controls) on number of weeks in subsequent re-employment (2014-2015).

The third part of the analysis tests the stability of the factors over time. Factorial instability would limit the usefulness of the factors as predictors of re-employment. To conduct this part of the analysis, I repeat the exploratory factor analyses on the 2014 data to discern whether the factors mimic the factors found by the analysis on the 2013 data and repeat the regression this time using the 2014 factors and limiting the dependent variable to only include weeks of unemployment in 2015. Then, I conduct a confirmatory factor analysis using a structural equation model (Hooper et al., 2008; Schreiber et al., 2006), which enables using the variable loadings of each of the 2013 factors on the corresponding 2014 variables and compare the Chi goodness-of-fit-tests between this model and a model not restricting the variable loadings of the 2014 data. This enables testing for stability over time. I compare the results of this model with the results of a nonrestricted structural equation model on the 2014 variables. If the factors remain stable over time, then the two models should yield similar Chi-squared values.

All analyses were conducted using STATA 13 (StataCorp. 2013, Stata Statistical Software: Release 13, StataCorp LP, College Station, Texas, USA). 


\section{Data}

The data for the present study derive from two sources. The first part of the data stems from the Copenhagen Unemployment and Well-Being Panel Survey, which was conducted via telephone (CATI) in 2013 and 2014. The study sample comprises 2400 people between 30 and 58 years of age ${ }^{9}$ living within Copenhagen municipality in Denmark who were registered with job center authorities as having applied for or receiving unemployment benefits as of August 26, 2013. The respondents had moreover been assessed by job center caseworkers as having problems aside from unemployment (such as social or health problems), but nevertheless as being sufficiently well to participate in activation programs (the historic administrative category of unemployed people 'Matchgruppe 2'). These survey participants constitute a randomly selected sample representing $21 \%$ of the disadvantaged cash benefit recipients from this group in the Copenhagen municipality, Denmark ${ }^{10}$.

With a completion rate of $40 \%, 956$ respondents participated in the first wave of the survey in 2013 , and $50 \%$ of the original respondents $(\mathrm{N}=474)$ participated in the second wave of the survey in 2014. Attrition was higher among males and non-ethnic Danes. Males constitute $46.13 \%$ of the overall sample and $43.93 \%$ of the respondents who participated in the first wave of the survey. The number of all respondents whose country of origin is not Denmark constitutes $47.46 \%$ of the sample. This group is somewhat less represented $(38.18 \%)$ in the group of all participants in the first wave of the survey. No pertinent mean age difference was observed between respondents from the study and sampled people who did not participate (results available upon request). Overall, the attrition rate suggests that the results could be skewed toward an over-representation of females and ethnic Danes. The attrition is highly unlikely to have invalidated the overall analysis, but is worth considering when examining the study findings.

The second data source is extensive register data linked at an individual level to each respondent by Statistics Denmark. The register data consist of background information (e.g., gender, age, country of origin, previous unemployment periods, educational attainment) and cash recipient status (not receiving cash benefits is a strong indicator of selfsupport and re-employment) measured weekly from 1991 to 2015. The data provide a detailed measure of unemployment and of likely re-employment of the unemployed panel survey participants between and after the two survey waves.

Table 1 provides an overview of the data sources used in each part of the analysis. The data from the first wave of the Copenhagen Unemployment and Well-Being Panel

Table I Data used in the three parts of the analysis

\begin{tabular}{|c|c|c|c|}
\hline \multirow[t]{2}{*}{ Part of the analysis } & \multicolumn{3}{|l|}{ Data set } \\
\hline & $\begin{array}{l}\text { The Copenhagen } \\
\text { Unemployment and } \\
\text { Well-Being Panel } \\
\text { Survey, wave I (2013) }\end{array}$ & $\begin{array}{l}\text { The Copenhagen } \\
\text { Unemployment and } \\
\text { Well-Being Panel Sur- } \\
\text { vey, wave } 2(2014)\end{array}$ & $\begin{array}{l}\text { Register data: Employment } \\
\text { status measured weekly for } \\
\text { each survey participant from } \\
\text { |99| to } 2015 \text {, controls }\end{array}$ \\
\hline I. Factor structure & $x$ & & \\
\hline 2. Predictive validity & $x$ & & $x$ \\
\hline 3. Factor stability & $x$ & $x$ & $x$ \\
\hline
\end{tabular}


Survey (2013) were used in each part to explore the factor structure of the relevant variables. The data from the second wave of the survey (2014) were used in the second part of the analysis to test the stability of the indicator. In the third part of the analysis, register data on employment status for each survey participant measured weekly from 1991 to 2015 were used for a control variable on previous unemployment and for the outcome variables enabling to investigate the predictive validity of each factor of the employability indicator.

\section{Variables}

\section{Factor analysis variables (survey data)}

In the factor analysis, I used variables from the first wave of the Unemployment and Well-Being Panel Survey. To measure physical or overall health, I used mainly global, or, single-item, measures (Youngblut \& Casper, 1993). I included variables into the survey aiming at employing previously used and validated questionnaire questions. I include a global health measure [similar to one used in the European Social Survey (2010)]. Corresponding to the well-being literature treating well-being, mental health, life satisfaction, and happiness as related or interchangeable concepts (see, e.g., Diener, 1994; Diener et al., 1999; Taylor \& Brown, 1988), I used a proxy measure for mental health consisting of a measure for global happiness and global life satisfaction [similar to questions from the European Social Survey (2010)].

To measure alcohol use, I used two indicators of alcohol use: a question about alcohol consumed within the previous week and the number of times of binge-drinking (consuming five or more drinks in one sitting) in the previous month [related to questions from the Health and Illness (SUSY) survey (National Institute of Public Health, 2010)]. To measure drug use, I used a variable measuring the number of times that marijuana was consumed within the previous month [similar to one used in the SUSY survey (National Institute of Public Health, 2013)] and the number of times that other substances were used in the previous month. To measure specific self-efficacy (here: job selfefficacy), inspired by Bandura's presentation of self-efficacy as being specific, as opposed to general (2006), I used self-reports of whether a respondent expects to be employed a year later and whether he or she expects to be able to work a year from now.

\section{Dependent variable: Unemployment (register data)}

Several studies within the field of labor market studies use the absence of receiving benefits as an indicator of employment (Bach, 2012; Graversen \& van Ours, 2008; Høgelund, Holm, \& Eplov, 2012; Høgelund, Holm, \& McIntosh, 2010; Svane-Petersen \& Dencker-Larsen, 2016), as does the present study. Using register data, unemployment is measured based on unemployment benefits received per week at an individual level for each week in 2014 and 2015. In other words, the present dependent variable is an indicator of financial self-support (similar to the measure of self-support in Nielsen et al., 2014). Self-support is when a person is no longer financially supported by unemployment benefits. In certain cases, the lack of unemployment benefits indicates that the person may 
have no income or have switched from one type of welfare benefits to another (e.g., from cash benefits to early retirement benefits). The lack of unemployment benefits is considered here to indicate the likely condition of a person no longer receiving unemployment benefits because of becoming re-employed and earning an income from his or her job.

The continuous unemployment variable counts the number of weeks in which a person receives unemployment benefits in 2014 and 2015; this variable thus spans 0-105 weeks. The higher the value of this variable, the more weeks the person has received unemployment welfare benefits in 2014 and 2015. Weeks receiving no unemployment benefits are recorded in the registers and are in the outcome variable regarded as indicators of re-employment.

\section{Control variables (survey and register data)}

Control variables are used in the third part of the analysis to test the predictive validity of each factor. The control variables derive from the following two sources: a) the Copenhagen Unemployment and Well-Being Panel Survey and b) register data linked to the survey data. The control variables are gender, age, country of origin, educational attainment, and previous unemployment, measured as the number of weeks from 1991 to 2012 in which a respondent received unemployment benefits. In the regression models, I also include an interaction between age and previous unemployment.

Table 2 displays the descriptive statistics of the variables for the three parts of the analyses. The respondents in the analytical sample are mostly women $(56.07 \%)$ and most respondents indicate Denmark as their country of origin $(61.82 \%)$. The mean age of the analytical sample is 44 years. The highest level of education for slightly less than

Table 2 Sociodemographic characteristics of the sample $(N=956)$

\begin{tabular}{lc}
\hline Control variables & Mean (SD) \\
\hline Age $(\mathrm{N}=956)$ & $44.25(7.61)$ \\
Previous employment between 199| and 20 I2, no. & $587.26(284.94)$ \\
of weeks $(\mathrm{N}=956)$ & Percent \\
& 43.93 \\
Male $(\mathrm{N}=956)$ & \\
Country of origin $(\mathrm{N}=956)$ & 61.82 \\
Denmark & 38.18 \\
Not Denmark & \\
Educational attainment $(\mathrm{N}=947)$ & 39.7 \\
Compulsory schooling & 13.41 \\
High school & 31.05 \\
Vocational training & 4.54 \\
Post-secondary education, I-2 years & 7.5 \\
Post-secondary education, 3-4 years & 3.06 \\
Post-secondary education, 5+ years &
\end{tabular}




\section{Factor analysis variables, 2013 wave}

Global health $(N=95 \mathrm{I})$

Very good

Good

Neither good nor bad

$\mathrm{Bad}$

Very bad

Alcohol use I (No. of drinks in the previous week) $(\mathrm{N}=938)$

0

Alcohol use 2 [No. of times of binge-drinking ( 5 or more drinks in one sitting) in the previous month] $(\mathrm{N}=94 \mathrm{I})$

0

$4+$

Drug use I (No. of times consumed marijuana in the previous month) $(\mathrm{N}=944)$

0

Drug use 2 (No. of times used other substances in the previous month) $(\mathrm{N}=953)$

\section{Mean (SD)}

Job self-efficacy I (Do you believe that you will have a job a year from now? $(\mathrm{N}=889,[0,10]$, from yes, highly so to no, highly so)

Job self-efficacy 2 (Do you believe that you will be able to work a year from now?) $(\mathrm{N}=888,[0,10]$, from yes, highly so to no, highly so) 
Global quality of life ( $\mathrm{N}=924,[0,10]$, from high
quality of life to low quality of life)

Dependent variables

Unemployed in 2014 and 2015, no. of weeks ( $N=$ $\left.948,\left[0,105^{\prime \prime}\right]\right)$

Unemployed in 2015 , no. of weeks** $(N=465$, $[0,53])$
$4.29(13.11)$

$93.83(24.31)$

$46.67(15.48)$

* Due to data protection policies of Statistics Denmark, I cannot display the precise distributions of the three other categories (as they are $N<5$ ). The low $N$ likely influences that this variable was eventually excluded from the final factor analysis due to a low correlation with the other substance use variable (please see the Results section).

** This version of the dependent variable is used only to test the stability of the predictive validity of the factors over time, so the reported values are restricted to the respondents participating in the 2014 wave $(\mathrm{N}=474)$.

two-fifths of the sample is compulsory schooling, while approximately one-sixth of the sample $(15.1 \%)$ completed post-secondary education. The mean number of previous weeks of unemployment between 1991 and 2012 is 587, but with a large standard deviation. This result indicates a large degree of variation between the respondents with respect to previous unemployment. Because this variation may be caused by respondents of different ages being employed different numbers of weeks, I include an interaction variable between age and number of weeks of previous unemployment in the regression models.

Concerning the factor analysis variables, the majority of respondents from the 2013 wave report that their health is 'bad' or 'very bad', while nearly a quarter of respondents report that they are in 'neither good nor bad' health. Slightly more than one-fifth of respondents report being in 'good' or 'very good' health. Most respondents report no alcohol consumption, no binge-drinking, no marijuana consumption, and no other drug use. The mean job self-efficacy of the two job self-efficacy variables is relatively low, approximately 7 on a scale from 0 to 10 ranging from a high to a low degree of job self-efficacy. However, the standard deviation of the job self-efficacy variables is approximately 3 , indicating a large degree of variation in the replies to the two job self-efficacy variables. Global happiness has a mean of slightly less than the midpoint of the five-point Likert scale and a standard deviation of 2.39, indicating that the respondents are typically experiencing neither very high degrees nor very low degrees of happiness. The mean global quality of life score is similar to this, but has a standard deviation of 1.13 and less variation in the responses to this variable.

The mean of the sample for the number of weeks unemployed in 2014 and 2015 is approximately 94 weeks of a total 105 weeks. The standard deviation of slightly greater than 24 weeks indicates considerable variation in the number of weeks of unemployment in the analytical sample.

\section{Results}

Table 3 summarizes the results of the first part of the analysis, namely the exploratory factor analysis used to reveal the factor structure of the variables hypothesized to 
Table 3 Factor structure and Cronbach's alphas for the 2013 data $(N=839)$

\begin{tabular}{|c|c|c|c|c|c|}
\hline \multirow[b]{2}{*}{ Factors and variables } & \multirow[b]{2}{*}{ Alpha } & \multicolumn{4}{|c|}{ Factors in the indicator of employability } \\
\hline & & Factor I & Factor 2 & Factor 3 & $\begin{array}{c}\text { Uniqueness } \\
\text { of item }\end{array}$ \\
\hline Factor I: Health/well-being & 0.77 & & & & \\
\hline Global health & & 0.36 & 0.33 & & 0.75 \\
\hline Global happiness & & 0.85 & & & 0.26 \\
\hline Global life satisfaction & & 0.85 & & & 0.26 \\
\hline Factor 2: Health/self-efficacy & 0.72 & & & & \\
\hline $\begin{array}{l}\text { Expect to be employed a year } \\
\text { from now }\end{array}$ & & & 0.8 & & 0.34 \\
\hline $\begin{array}{l}\text { Expect to be able to work a year } \\
\text { from now }\end{array}$ & & & 0.81 & & 0.33 \\
\hline Factor 3:Alcohol use & 0.82 & & & & \\
\hline No. of drinks & & & & 0.78 & 0.39 \\
\hline No. of times of binge-drinking & & & & 0.78 & 0.39 \\
\hline
\end{tabular}

The eigenvalues of the first, second, and third factors are 2.07, I.2, and I.0 I, respectively.

The factors are defined using principal component factors and rotated using the oblimin rotation.

indicate employability. The correlation matrix showed values far below 0.3 between the drug use questions (results available upon request), which, in the preliminary analysis, represented a fourth factor, namely drug use. The low correlation values indicate a weak relationship between the two drug use questions. Accordingly, the two questions were deleted from the factor analysis. With eigenvalues $>1$, the remaining variables reveal a factor structure of three factors, based on the eigenvalues-greater-than-one rule proposed by Kaiser (Cliff, 1988). The first factor, health/well-being, comprises the global health measure, the global happiness measure, and the global quality of life measure. The second factor, health/self-efficacy, comprises the global health measure (again, but this time with a somewhat smaller loading on the second factor than was the case on the first factor) and the two job self-efficacy variables. The third factor, alcohol, comprises the two alcohol variables. The factor structure of each variable is supported by the relatively high Cronbach's alpha values in the range 0.72-0.82 indicating congruence in correlation between the variables in each factor.

The second part of the analysis uses regression analysis to investigate whether these three factors predict subsequent re-employment. I employ the number of weeks in unemployment in 2014 and 2015 as an outcome measure. When interpreting Table 4, it is important to note that the responses to both the outcome variable and the factor variables tend toward 'poor'. The findings are presented in Table 4, which shows that only the second factor, health/self-efficacy, has statistically significant predictive power on the number of weeks of unemployment in 2014 and 2015. The first factor, health/wellbeing, increases the number of weeks of unemployment, and the third factor, alcohol use, decreases the number of weeks in unemployment, but these two factors are not statistically significantly related to the unemployment outcome variable. Only one control 
Table 4 Predictive validity of each factor $(N=831)$

$\beta$, number of weeks of unemployment in 2014 and 2015 (95\% confidence intervals)

\author{
Factor I: Health/well-being (toward poor) \\ Factor 2: Health/self-efficacy (toward poor) \\ Factor 3: Alcohol (increasing alcohol consumption) \\ Male
}

$1.39(-0.23$ to 3.01$)$

2.35 (0.62-4.08)

$-1.13(-3.02$ to 0.77$)$

$-3.29(-6.38$ to -0.19$)$

Statistically significant results at the 95\% significance level are bolded.

Only statistically significant control variables are included in the table.

Adjusted for: gender, age, previous unemployment, age* previous unemployment, country of origin, and educational attainment.

The $r^{2}$ value for the model is 0.0889 (i.e., $8.89 \%$ of the variance in data can be explained by the included variables).

variable, gender, exerts a statistically significant impact on the number of weeks of unemployment. Specifically, being male decreases the number of weeks of unemployment.

The third part of the analysis tested the stability of the factors over time and includes an exploratory factor analysis that was repeated on the 2014 data, a repeated analysis of predictive validity, and a confirmatory factor analysis using structural equation modeling. These analyses reveal mixed findings. The exploratory factor analysis conducted on the 2014 data includes the 2014 data on the same variables which were used in the factor analyses of the 2013 data. The factor structure of the 2014 variables is nearly identical to that found for the 2013 data, albeit the first and second factors 'switch places', and the alcohol use factor decreases to 0.86 (below the eigenvalues-greater-than-one rule threshold), thus suggesting that alcohol use is not present as a factor in the 2014 dataset (results available upon request). By contrast, when analyzing the stability of the predictive validity of the 2014 exploratory factors, the results mimic those from the analyses on the 2013 data: the factor indicating health/self-efficacy is linked with subsequent re-employment (results available upon request).

Results from the confirmatory factor analysis using the loadings of the 2013 factors on the relevant 2014 variables in a structural equation model, however, are discouraging. The Chi-square goodness-of-fit value differs markedly between the structural equation model using the 2013 loadings on the 2014 variables and the nonrestricted structural equation model using the 2014 data (results available upon request). This difference reveals a low degree of factor stability over time between the 2013 and the 2014 respondents. Overall, the findings from the third part of the analysis suggest that the factors are not stable over time, but that health/self-efficacy has predictive validity over time.

\title{
Discussion
}

Overall, this article develops and tests an indicator of employability for disadvantaged unemployed people receiving cash benefits. The ambition was that the indicator could be used as an outcome measure capturing more nuances than the traditional outcome measures, re-employment in evaluations of activation programs that were hypothesized to 
not show clear findings because of disadvantaged unemployed people not easily becoming re-employed. The proposed indicator was to be used in evaluations of activation programs (as well as in other types of labor market studies) in Denmark and the Nordic countries. The analysis consisted of three parts: 1 ) exploring the factor structure of variables that are likely to be linked with re-employment chances, 2) testing whether each of the three emerging factors have predictive validity on subsequent re-employment, and 3) testing the stability of the indicator and its predictive validity over time. Overall, the findings suggest that the indicator in its current form is not applicable to be used in studies to assess the employability of disadvantaged unemployed people. I will, however, argue that the analyses are an important step in the direction of evaluating how (if at all) an indicator of employability for disadvantaged unemployed people could be developed. In this section, I introduce and consider possible explanations and interpretations of the findings.

From the literature in the area, the expected findings were that physical or overall health, mental health, alcohol use, drug use, and job self-efficacy matter for disadvantaged unemployed people. The findings from the first part of the analysis are, for the most part, in line with this. Considering that much research has shown that health is a predictor of re-employment chances for unemployed people, the finding that health plays a role in two of the factors further supports existing research. The factor analysis shows links between several of the proposed variables, and indeed extrapolates three factors. However, the drug use variables are dropped from the factor analysis, because they appear to not be substantially linked to the other variables of interest (nor, indeed, among themselves). This suggests that drug use, important as it likely is in many instances, is not strongly linked with the other aspects expected to be of importance to disadvantaged unemployed people's employability and re-employment chances.

Furthermore, the expected findings were that the factors should be linked with subsequent re-employment. This, however, is only the case for one of the factors. This suggests that there may be entirely different factors at stake for this group's re-employment chances. For instance, this could be a strong worker identity as suggested by a qualitative study of disabled unemployed people (Mettävainio \& Ahlgren, 2009). It could also suggest that the group may be too diverse for a single measure of employability to capture key aspects of what impacts re-employment chances. This point is supported by a qualitative study on older unemployed workers in the UK describing a complex experienced reality of, for example, how they experience being viewed by others, including job centre officials and potential employers, compared with how they view themselves (Riach \& Loretto, 2009). Additionally, this notion of potential discrepancies between unemployed workers and potential employers poses the question whether the demand side of employment plays a role in the findings being less-than-straight-forward to interpret. For instance, poor health of job seekers can impede job search (Carlier et al., 2014) and employers are reluctant to hire applicants with health problems (Black, 2008; Brink Thomsen et al., 2011; Rosenstock et al., 2004). Future studies aiming at developing measures of employability may benefit from including items on the demand side.

Concerning the statistical implications of the analyses, the first part of the analysis revealed a factor structure of three factors. The factors are health/well-being, health/ self-efficacy, and alcohol. Whether the combination of health and well-being in one factor suggests that overall and mental health are linked, is unclear to determine, but is tentatively indicated by the data. Surprisingly, the factor structure revealed that job 
self-efficacy and well-being are both linked with health. Considering the relatively low factor analysis uniqueness scores of these variables and the relatively high uniqueness score of the health variable, this finding suggests that job self-efficacy in itself and that well-being in itself are not (as) relevant to the re-employment chances of disadvantaged people; rather, only in combination with health do these variables influence number of weeks in unemployment. Third, as expected from the literature emphasizing the potential importance of alcohol use on re-employment chances, alcohol use as a factor comprises the two thematically linked alcohol variables.

The second part of the analysis showed that only the second of the three factors from the 2013 wave, health/self-efficacy, had statistically significant predictive validity on re-employment in 2014 and 2015. This finding suggests that only aspects of the proposed indicator of subsequent re-employment indeed indicate subsequent re-employment. In a robustness check of this finding, I included the variables from the factor analysis (this time as separate variables and not as factors), including controls, in a regression model. I was thus able to test whether each variable in itself appeared to affect subsequent re-employment. The results from this robustness check revealed that only one of the included variables from the factor analysis (no. of drinks per week) and neither of the controls had statistically significant predictive validity on subsequent re-employment chances (results available upon request). This finding suggests the usefulness of developing an indicator using latent factors combining variation from several variables (such as the present indicator does) rather than relying on, for example, regression analyses using individual variables only.

Additionally, I conducted a robustness check investigating the assumption that the factors are key in measuring employability of disadvantaged unemployed people. Expanding the regression model analyzing predictive validity by including interactions between the factors and the control variables further discourages use of the indicator in its present state. Adding interactions between the factors and control variables changes which variables are statistically significant - and this again changes depending on which of these interaction effects are added in the regression model. The majority of the variables added in the model remain statistically insignificant for subsequent re-employment. One interpretation of the findings from this robustness check is that the indicator does not capture key employability aspects. Another is that it simply may not be feasible to develop an indicator that allows upwards and downwards fluctuation over time - and that the field must rely solely on screening tools [including elements such as age, sex, and education level and training that either cannot be influenced by caseworkers (age and sex), or, which only allow for stagnation or an increase and not a decrease after participation in activation programs (education level and training)].

Despite these both mixed and discouraging findings, I will argue that there may still be potential in the development of employability indicators for disadvantaged unemployed people. For instance, one could presume that background factors could affect how well employability is measured. For instance, following the literature on human capital (Blundell et al., 1999; Fugate et al., 2004), education level may impact the employability of workers. This opens for the assumption that perhaps certain education levels allow for more fluctuation on the indicator than others, providing a potential explanation of the discouraging findings from the overall analyses. This could suggest that an initial screening in to different sub-types of employability indicators depending on, for example, the education level of the unemployed person, could be the route that

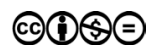


research in this area could take. The robustness check adding indicators to the regression model, however, neither clearly supported nor clearly discouraged this line of inquiry.

The third part of the analysis involved stability testing the indicator. When conducting an exploratory factor analysis on the 2014 data, the factors are relatively similar. Surprisingly, the factors switch places so that the first factor becomes the second factor, and the second factor becomes the first factor of the factor model. When conducting a structural equation model on the 2014 data and comparing with the 2013 factor coefficients, the results are discouraging. The difference in the goodness-of-fit Chi-squared test results from the structural equation models strongly suggests that the factor structure is not stable between 2013 and 2014. As a supplementary test of the stability of the factors over time, the exploratory factor analysis of the 2014 data indicates, similarly to the 2013 findings, that the factor health/self-efficacy has predictive validity for subsequent re-employment in a regression analysis of re-employment in 2015.

As an additional robustness check, I conducted a first differences regression using the difference between the 2014 and 2013 unemployment weeks explained by the difference between the 2014 factors and the 2013 factors. The results were statistically insignificant for each of the factors on re-employment (results available upon request). This suggests that despite there being predictive validity, the link between health/self-efficacy and re-employment is not causal in nature. The link between health/self-efficacy and reemployment is through, for example, another variable or index affecting both the health/ self-efficacy factor and re-employment. This result suggests uncertainty regarding how employability of disadvantaged unemployed people could be increased most effectively.

The mixed and discouraging findings may be linked with another potential measurement uncertainty: the causality of job self-efficacy and subsequent re-employment. On the one hand, studies support the potential impact of (job search) self-efficacy on subsequent employment [see, e.g., (Saks \& Ashforth, 1999) (for a study on university graduates and the Finnish data on the Työhön Job Search Intervention focusing on jobsearch self-efficacy and inoculation against setbacks indicates that an intervention to increase the to-job-self-efficacy-related term 'job search self-efficacy' indeed does affect job search preparedness, which was found to be a mediator of subsequent re-employment (Vuori \& Vinokur, 2005)]. On the other hand, one could question one of the two variables used in the present study to measure job self-efficacy. Respondents' replies to the phrasing 'expect to hold a job a year from now' could have been affected by whether or not he or she had an inclination of - or an already arranged starting day - working at a specific job. If some of the respondents who replied positively to this statement did so because they had already had acquired a job, this could be one of the potential explanations for the robustness check showing a lack of causality between the health/ job self-efficacy factor and subsequent re-employment.

Overall, the stability tests and robustness check show mixed results strongly tending toward being discouraging, and indicate a lack of stability in factor structure over time. These results may be influenced by the difference in composition of the 2013 respondents and the 2014 respondents (consisting of only around half of the 2013 respondents). Additionally, some of the respondents may have become re-employed (for varying time periods) between the 2013 sampling date and the 2014 second wave. When examining the attrition between the 2013 and 2014 waves, the share of respondents whose country of origin is not Denmark decreases from approximately $38 \%$ to approximately $30 \%$, while the gender distribution and the mean age remain approximately constant (results 
available upon request). The decreased proportion of respondents whose country of origin is not Denmark may have influenced the stability of the results.

However, handling the attrition by restricting the sample to consist only of respondents who participated both years and conducting the confirmatory factor analysis on this sample does not noticeably improve the stability of the factors between 2013 and 2014. Another possible interpretation of the findings from the structural equation models is that in a sample of all-unemployed respondents, changes (such as periods of reemployment in between unemployment or unobserved life transitions) when following this group to the subsequent year impact the stability of the respondent's survey replies. Overall, the findings from the stability tests suggest a lack of stability, and that further analyses on longitudinal data on disadvantaged unemployed people are required.

Not only the attrition between 2013 and 2014, but also the attrition between the sampled respondents and the 2013 participants, must be discussed. The attrition rate from the sampled respondents to the participants in the 2013 wave is greater than half of the sampled respondents, due particularly to the withdrawal of males and people born outside Denmark. The overall results from the study may be affected by this change in the composition of the 2400 sampled respondents and the 956 participants in the first wave of the survey. A possible interpretation is that the results are representative of the responses of both men and women, but more so for women, and likewise for both people whose country of origin is Denmark and for people whose country of origin is not Denmark, but mainly for those whose country of origin is Denmark.

Finally, concerning the generalizability of the findings from the study, both the overall strengths and the overall limitations of the present study can be traced to the narrow scope of the data. On the one hand, the narrow scope [unemployed cash benefit recipient Copenhageners in the administrative (and historic) administrative category 'Matchgruppe 2'] supports the interpretation that the variation in data is not caused by, for instance, systematic differences between groups or across countries. On the other hand, the narrow scope also suggests that the analyses should be replicated using data on disadvantaged unemployed people from other regions of Denmark, other similar countries, such as the Nordic countries, and across groups of disadvantaged unemployed people, before drawing inferences regarding the scope of the findings.

\section{Conclusion}

The present study aimed at developing an indicator of employability to enable more nuanced analyses of social and labor market policies such as activation programs. In conclusion, the findings propose that the indicator - as is - is not applicable to studies evaluating the usefulness of activation program participation for disadvantaged unemployed people. What the findings do suggest, however, I argue, is that this study is an important step along the way of empirically disentangling what matters for the employability of disadvantaged unemployed people, and how this can and cannot be measured. Furthermore, the finding that one of the factors, health/self-efficacy, correlates with subsequent re-employment (despite the relationship not being causal), and that the variables included in the factors (except for a single variable) do not have statistically significant predictive validity when placed separately into a regression model, suggests that studies aiming at developing indicators of employability could benefit from using data reduction techniques such as factor analysis. 
I propose that further analyses be conducted on the topic using other Danish and Nordic data to adjust the proposed indicator, particularly to test whether an indicator of employability can be derived from other or similar variables using data reduction techniques such as factor analysis - and whether other perspectives, such as the employer perspective, influence the re-employment chances of disadvantaged unemployed people and should be included in the development of an indicator of employability.

\section{References}

Agresti, A., \& Finlay, B. (1997). Statistical methods for the social sciences (Vol. 3). Upper Saddle River, N.J.: Prentice Hall.

Bach, H. B. (2012). Arbejdsmarkedsparathed og selvforsørgelse [Readiness-for-work and self-support]. Copenhagen: SFI - The Danish National Centre for Social Research. doi: https://dx.doi.org/pure.sfi.dk/ws/files/232892/1231 Arbejdsmarkedsparathed.pdf.

Bandura, A. (2006). Guide for constructing self-efficacy scales. https://www.uky.edu/ eushe2/ Bandura/BanduraGuide2006.pdf.

Black, C. M. (2008). Working for a healthier tomorrow. Norwich: The Stationery Office.

Blundell, R., Dearden, L., Meghir, C., \& Sianesi, B. (1999). Human Capital Investment: The Returns from Education and Training to the Individual, the Firm and the Economy. FISC Fiscal Studies, 20(1), 1-23.

Briggs, S. R., \& Cheek, J. M. (1986). The role of factor analysis in the development and evaluation of personality scales. JOPY Journal of Personality, 54(1), 106-148.

Brink Thomsen, L., Holt, H., Jensen, S., \& Thuesen, F. (2011). Virksombeders sociale engagement: Årbog 2011 [Corporate Social Responsibility: Yearbook 2011]. Copenhagen: SFI The Danish National Centre for Social Research.

Carlier, B. E., Schuring, M., van Lenthe, F. J., \& Burdorf, A. (2014). Influence of Health on Job-Search Behavior and Re-employment: The Role of Job-Search Cognitions and Coping Resources. Journal of Occupational Rehabilitation, 24(4), 670-679.

Claussen, B. (1993). A clinical follow up of unemployed II: Sociomedical evaluations as predictors of re-employment. pri Scandinavian Journal of Primary Health Care, 11(4), 234-240. doi: http://www.tandfonline.com/doi/pdf/10.3109/02813439308994837.

Claussen, B. (1999a). Alcohol disorders and re-employment in a 5-year follow-up of longterm unemployed. Addiction, 94(1), 133-138. doi: http://dx.doi.org/10.1046/j.13600443.1999.94113310.x.

Claussen, B. (1999b). Health and re-employment in a five-year follow-up of long-term unemployed. Scandinavian Journal of Public Health, 27(2), 94-100.

Cliff, N. (1988). The eigenvalues-greater-than-one rule and the reliability of components. Psychological Bulletin Psychological Bulletin, 103(2), 276-279.

Cochran, W. G. (1977). Sampling techniques (Vol. 3). New York: John Wiley \& Sons, Inc.

Daniel, M., Cargo, M., Marks, E., Paquet, C., Simmons, D., Williams, M., ... Odea, K. (2009). Rating Health and Social Indicators for Use with Indigenous Communities: A Tool for Balancing Cultural and Scientific Utility. Soc Indic Res Social Indicators Research : An International and Interdisciplinary Journal for Quality-of-Life Measurement, 94(2), 241-256.

Dencker-Larsen, S. (2013). Studying factors affecting the unemployed. Danish Social Research.News from SFI, 2013(3).

Diener, E. (1994). Assessing subjective well-being: Progress and opportunities. Social Indicators Research: An International and Interdisciplinary Journal for Quality-of-Life Measurement, 31(2), 103-157. 
Diener, E., Suh, E. M., Lucas, R. E., \& Smith, H. L. (1999). Subjective well-being: Three decades of progress. Psychological bulletin, 125(2), 276-302.

Elo, A. L., Leppänen, A., \& Jahkola, A. (2003). Validity of a single-item measure of stress symptoms. Scandinavian journal of work, environment \& health, 29(6), 444-451.

European Social, S. (2010). Spørgeskema. ESS. 5. runde 2010 [Questionnaire. ESS. 5th round 2010]. https://www.europeansocialsurvey.org/docs/round5/fieldwork/denmark/ESS5 main questionnaire DK.pdf.

Fugate, M., \& Kinicki, A. J. (2008). A dispositional approach to employability: Development of a measure and test of implications for employee reactions to organizational change. Journal of Occupational and Organizational Psychology, 81(3), 503-527.

Fugate, M., Kinicki, A. J., \& Ashforth, B. E. (2004). Employability: A psycho-social construct, its dimensions, and applications. YJVBE</cja:jid > Journal of Vocational Behavior, 65(1), $14-38$.

Geerdsen, L. P. (2006). Is there a Threat Effect of Labour Market Programmes? A Study of ALMP in the Danish UI System. The Economic Journal, 116(513), 738-750.

Graversen, B. K. (2011). Teettere på arbejdsmarkedet?: Om effektmåling af beskceftigelsesindsatsen for ikke-arbejdsmarkedsparate ledige [Closer to the labour market? About studying the effect of labour market policy and programmes for unemployed people assessed by caseworkers to have problems hindering them from employment]. Copenhagen: SFI - The Danish National Centre for Social Research.

Graversen, B. K., \& van Ours, J. C. (2008). How to help unemployed find jobs quickly: Experimental evidence from a mandatory activation program. Journal of Public Economics, 92(10-11), 2020-2035.

Halvorsen, K. (2000). Sosial eksklusjon som problem. En kritisk vurdering af begrebet sosial eksklusjon med spesiell referanse til dagens Norge [Social exclusion as a problem. A critical assessment of the term social exclusion with particular reference to Norway today]. Tidsskrift for Velferdsforskning, 3(3), 157-171.

Henriksen, A. C. (2010). Veje til beskaftigelse: En kvalitativ undersøgelse af indsatser over for ikke-arbejdsmarkedsparate kontanthjoelpsmodtagere [Roads towards employment: A qualitative inveatigation on programmes targeting unemployment welfare benefit recipients assessed to have problems aside from unemployment]. Copenhagen: SFI - The Danish National Centre for Social Research.

Hillage, J., \& Pollard, E. (1998). Employability : developing a framework for policy analysis (085522889X 9780855228897). Retrieved from Suffolk:

Hobbins, J. (2016). Young Long-term Unemployed and the Individualization of Responsibility. NJWLS Nordic Journal of Working Life Studies, 6(2), 43.

Hooper, D., Coughlan, J., \& Mullen, M. R. (2008). Structural equation modelling: Guidelines for determining model fit. Electron.J.Bus.Res.Methods Electronic Journal of Business Research Methods, 6(1), 53-60.

Høgelund, J., Holm, A., \& Eplov, L. F. (2012). The effect of part-time sick leave for employees with mental disorders. The journal of mental health policy and economics, 15(4), 157-170.

Høgelund, J., Holm, A., \& McIntosh, J. (2010). Does graded return-to-work improve sick-listed workers' chance of returning to regular working hours? Journal of Health Economics, 29(1), 158-169.

jobindsats.dk. (2016). Fordelingsvariable [Variables]. http://www.jobindsats.dk/jobindsats/ hjaelp/fordelingsvariable.aspx.

Jobnet, A. (2016). Ordforklaring [Word definitions]. https://info.jobnet.dk/ordforklaring.

Johansson, H. (2001). Activation Policies in the Nordic Countries: Social Democratic Universalism under Pressure. Journal of Contemporary European Studies, 9(1), 63-77.

Kadefors, R., \& Hanse, J. J. (2012). Employers Attitudes Toward Older Workers and Obstacles and Opportunities for the Older Unemployed to Reenter Working Life. NJWLS Nordic Journal of Working Life Studies, 2(3), 29. 
Kora, Aalborg, U., New, I., \& Væksthuset. (2012). Litteraturreview ifbm. BeskæftigelsesIndikatorProjektet [Literature Review in relations with the 'EmploymentIndicatorProject']. http:// www.jobindikator.dk/fileadmin/user upload/documents/pdf/Litteraturreview BeskaeftigelsesIndikatorProjektet.pdf.

Kristensen, C. J. (1999). Marginalisering - en begrebsudredning. Aalborg: Forskningsenheden Differentieret Social Integration, Aalborg Universitet.

Larsen, S. D. (2012). Toettere på arbejdsmarkedet. Hvilke faktorer øger sandsynligheden for, at ikke-arbejdsmarkedsparate ledige noermer sig arbejdsmarkedet? [Closer to the labour market. Which factors increase the chances of getting closer to the labour market for unemployed workers assessed to have problems aside from unemployment?]. Master's Thesis. Department of Sociology, University of Copenhagen, Copenhagen.

Lindegaard, H., \& Rosholm, M. (2016). The Effect of Changing Mental Health on Unemployment Duration and Destination States after Unemployment. doi: http://dx.doi.org/ ssrn.com/abstract $=1672026$.

Lynd-Stevenson, R. M. (1999). Expectancy-value theory and predicting future employment status in the young unemployed. Journal of Occupational and Organizational Psycholo$g y, 72(1), 101-106$.

Marston, G., \& McDonald, C. (2008). Feeling Motivated Yet?: Long-term Unemployed People's Perspectives on the Implementation of Workfare in Australia. Australian Journal of Social Issues, The, 43(2), 255-269.

McQuaid, R. W., \& Lindsay, C. (2005). The Concept of Employability. Urban Studies, 42(197).

Mettävainio, B. I., \& Ahlgren, C. (2009). Facilitating factors for work return in unemployed with disabilities: A qualitative study. Scandinavian Journal of Occupational Therapy Scandinavian Journal of Occupational Therapy, 11(1), 17-25. doi: http://dx.doi. org/10.1080/1138120410019054.

Morisky, D. E., Green, L. W., \& Levine, D. M. (1986). Concurrent and predictive validity of a self-reported measure of medication adherence. Medical care, 24(1), 67-74.

National Institute of Public Health (2010). Hvordan har du det? En national undersøgelse af trivsel, sundhed og sygdom blandt voksne danskere [How are you? A national survey on well-being, health, and illness amongst adult Danes]. http://www.si-folkesundhed.dk/ upload/susy 2010 spørgeskema.pdf.

National Institute of Public Health, H. (2013). Hvordan har du det? En national undersøgelse af trivsel, sundhed og sygdom blandt voksne danskere [How are you? A national survey on well-being, health, and illness amongst adult Danes]. http://www.si-folkesundhed.dk/ upload/sp \%C3\%B8rgeskema - susy2013.pdf.

Nielsen, M. B. D., Hansen, J. V., Aust, B., Tverborgvik, T., Thomsen, B. L., Bjorner, J. B., . . . Kristensen, N. (2014). A multisite randomized controlled trial on time to self-support among sickness absence beneficiaries. the Danish national return-to-work programme. Eur.J.Public Health European Journal of Public Health, 25(1), 96-102.

OECD, A. (2009). DENMARK 2009. Retrieved from http://www.oecd.org/denmark/47346737.pdf.

Pedersen, L. (2007). Effekter af aktivering - en gennemgang af danske forskningsresultater [effects of Active Labour Market Programmes - a presentation of findings from Danish research]. Tidsskrift for Velferdsforskning, 10(2), 103-115.

Bekendtgørelse af lov om en aktiv beskæftigelsesindsats [Legislation about active labour market policies], (2012).

Riach, K., \& Loretto, W. (2009). Identity work and the u'nemployed' worker: age, disability and the lived experience of the older unemployed. WORK EMPLOYMENT AND SOCIETY, 23(1), 102-119. 
Rosenstock, M., Tinggaard, K., Holt, H., \& Jensen, S. (2004). Rummelighedens rammer : anscettelsesmuligheder for personer med hjerneskade, sindslidelse eller udviklingshamning (8774877666 9788774877660). Retrieved from Copenhagen:

Saks, A. M., \& Ashforth, B. E. (1999). Effects of Individual Differences and Job Search Behaviors on the Employment Status of Recent University Graduates. Journal of Vocational Behavior Journal of Vocational Behavior, 54(2), 335-349.

Schreiber, J. B., Nora, A., Stage, F. K., Barlow, E. A., \& King, J. (2006). Reporting Structural Equation Modeling and Confirmatory Factor Analysis Results: A Review. The Journal of Educational Research, 99(6), 323-338.

Schuring, M., Robroek, S. J., Otten, F. W., Arts, C. H., \& Burdorf, A. (2013). The effect of ill health and socioeconomic status on labor force exit and re-employment: a prospective study with ten years follow-up in the Netherlands. Scandinavian journal of work, environment \& health, 39(2), 134-143.

Skipper, J. (2010). En mikroøkonometrisk evaluering af den aktive beskaftigelsesindsats. Retrieved from København:

Streiner, D. L., Norman, G. R., \& Cairney, J. (2014). Health Measurement Scales. A Practical Guide to Their Development and Use UK: Oxford University Press.

Sutton, L., Cebulla, A., Heaver, C., \& Smith, N. (2004). Drug and alcohol use as barriers to employment: a review of the literature. Retrieved from

Svane-Petersen, A. C., \& Dencker-Larsen, S. (2016). The impact of global self-reported health and register-based prescription medicine purchases on re-employment chances: A prospective study. Retrieved from http://www.sciencedirect.com/science/article/pii/ S2352827316300556.

Taylor, S. E., \& Brown, J. D. (1988). Illusion and well-being: A social psychological perspective on mental health. Psychological bulletin, 103(2), 193-210.

The Danish Agency for Labour, M., \& Recruitment. (2009). Notat: Ny matchmodel - hvorfor og hvordan? (Reprinted from: NOT IN FILE).

The Danish Agency for Labour, M., \& Recruitment. (2016). Kontanthjælp - hvis du er 30 år eller derover [Unemployment welfare benefits - if you are 30 years of age or older]. https://www.borger.dk/Sider/Kontanthjaelp-30-eller-derover.aspx.

The Danish National Audit, O. (2010). Beretning til Statsrevisorerne om effekten af aktivering af ikke-arbejdsmarkedsparate kontanthjolpsmodtagere [Report for the Danish Public Accounts Committee]. Retrieved from http://www.rigsrevisionen.dk/media/1824834/1-2010.pdf.

Vuori, J., \& Vinokur, A. D. (2005). Job-search preparedness as a mediator of the effects of the Työhön Job Search Intervention on re-employment and mental health. J. Organiz. Behav. Journal of Organizational Behavior, 26(3), 275-291. doi: https://dx.doi.org/10.1002/ job.308.

Youngblut, J. M., \& Casper, G. R. (1993). Focus on psychometrics: single-item indicators in nursing research. Research in Nursing \& Health, 16(6), 459-465.

\section{End notes}

${ }^{1}$ See also (Claussen, 1999b) for a study of long-term unemployed in Norway in which '[o]nly $37 \%$ were employed five years after the first spell of long-term unemployment'.

${ }^{2}$ For further information on this group of unemployed people and the applied administrative categories, please see The Danish Agency for Labour Market and Recruitment (2016; 2009).

${ }^{3}$ See also Dencker-Larsen (2013) and Larsen (2012).

${ }_{4}$ The literature review consisted of extensive searches of print sources and internet searches using both scholarly search engines and broader web searches on the topic.

5 Or factors related to self-efficacy. 
${ }^{6}$ For the caseworker perspective on this topic, see, for example, Henriksen (2010).

${ }^{7}$ It must be noted that some examples of indicators of re-employment chances already exist (for an overview, see Graversen, 2011). An example of such indicators is Danish consultancy firms developing questions for unemployed people or their caseworkers or other people to answer about the unemployed person. The previously existing indicators, however, lack sufficient testing and validation (Graversen, 2011).

${ }^{8}$ I use similar imagery and theoretical background in Larsen (2012).

9 The age of the respondents ranges between 30 and 58 years in 2013. The age range was chosen to ensure 1) that the unemployed people were affected by the same rules surrounding activation programmes (30-60 years of age) (retsinformation.dk [legislative information], 2012), and 2) that the survey should enable measuring the impact of activation programs between the two waves of the survey, so the respondents should not exceed 59 years of age at the time of the second wave of the survey (i.e., 2014).

10 The Copenhagen Unemployment and Well-Being Panel Survey was sampled using 'stratified random sampling' (Cochran, 1977). Its sample of 2400 respondents included individuals sampled from the group of unemployment cash benefit recipient who were not disadvantaged. These latter respondents were assessed by case workers as not having problems aside from unemployment that would inhibit them from securing re-employment (the historic 'Matchgruppe 1'). Both 'Matchgruppe 1' and 'Matchgruppe 2' were required by law to participate in activation programmes. In 2013, another group of unemployment benefit recipients was determined by case workers to be disadvantaged to an extent that the recipients were not recommended for participation in activation programs nor were they required to participate (the historic 'Matchgruppe 3'). The survey was not administered to this group. For further information on the three administrative groups ('Matchgruppe 1-3'), please see The Danish Agency for Labour Market and Recruitment (The Danish Agency for Labour \& Recruitment, 2009) and jobindsats.dk (jobindsats.dk, 2016)

11 The two outcome variables sum to 105 and 53, respectively. The number of weeks registered each year is typically 52, but in 2015, the number of weeks registered in the register data is 53 . 